JURNAL BASICEDU

Research \& Learning in Elementary Education

https://jbasic.org/index.php/basicedu

\title{
PENGARUH MODEL PEMBELAJARAN KOOPERATIF TIPE THINK PAIR SHARE TERHaDAP AKTIVITAS DAN HASIL BELAJAR PESERTA DIDIK
}

\author{
Nuri Hayatul Jannah', Mudjiran ${ }^{2}$ \\ Universitas Negeri Padang, Sumatera Barat, Indonesia ${ }^{1,2}$ \\ Email : nurihayatul_j@yahoo.co.id ${ }^{1}{ }$, mudjiran@konselor.org ${ }^{2}$
}

\begin{abstract}
Abstrak
Artikel ini bertujuan untuk membahas secara konseptual pengaruh model pembelajaran Think Pair Share pada aktivitas pesertadidik dan hasil belajar di sekolah dasar, menunjukkan bahwa dengan beberapa upaya yang telah dilakukan untuk membuat aktivitas anak / siswa melalui perubahan kurikulum dengan pembelajaran konvensional ke dalam pembelajaran saintifik, tetapi upaya belum dapat berjalan secara optimal, terutama kegiatan siswa yang semakin menurun, maka diperlukan upaya untuk meningkatkan proses pembelajaran, salah satunya adalah model pembelajaran kooperatif Think Pair Share karena sejalan dengan terintegrasi pesertadidik, berdasarkan pengamatan menunjukkan bahwa model pembelajaran Think Pair Share memiliki dampak yang baik jika dinilai dari segi aktivitas dan hasil belajar, secara konseptual bahwa model pembelajaran Think Pair Share dapat digunakan sebagai salah satu model yang sejalan dengan pembentukan kegiatan. dan memiliki dampak yang baik pada hasil belajar peserta didik
\end{abstract}

Kata Kunci: model pembelajaran Think pire share, aktivitas, hasil belajar

\begin{abstract}
This article aims to discuss conceptually the influence of Think Pair Share learning models on student activity and learning outcomes in primary schools, showing that with some efforts that have been made to make children's / student activities through curriculum changes with conventional learning into scientific learning, but efforts it has not been able to run optimally, especially student activities which are declining, so efforts are needed to improve the learning process, one of which is the Think Pair Share cooperative learning model because it is in line with integrated student participation, based on observation shows that the Think Pair Share learning model has a good impact if assessed in terms of activities and learning outcomes, conceptually that the Think Pair Share learning model can be used as a model that is in line with the formation of activities. and has a good impact on student learning outcomes
\end{abstract}

Keywords: Think pair share learning model, activities, learning outcomes

@ Jurnal Basicedu Prodi PGSD FIP UPTT 2019

$\triangle$ Corresponding author :

Address :

Email : nurihayatul_j@yahoo.co.id

ISSN 2580-3735 (Media Cetak)

Phone : ISSN 2580-1147 (Media Online) 
2126 Pengaruh model pembelajaran kooperatif tipe TPS terhadap aktivitas dan hasil belajar peserta didikNuri Hayatul Jannah, Mudjiran

\section{PENDAHULUAN}

Pendidikan memiliki peranan yang sangat penting dalam kehidupan manusia, karena dapat mempengaruhi perkembangan dalam segala aspek kepribadian dalam kehidupannya. Pendidikan pada hakikatnya merupakan usaha manusia untuk memanusiakan manusia itu sendiri, yaitu untuk membudayakan manusia.

Pendidikan adalah suatu proses dalam rangka mempengaruhi siswa agar dapat menyesuaikan diri sebaik mungkin terhadap lingkungannya dan dengan demikian akan menimbulkan perubahan dalam dirinya yang memungkinkannya untuk berfungsi secara dalam kehidupan masyarakat.(Hamalik 2012)

Pembelajaran tematik terpadu untuk SD/MI merupakan pendekatan pembelajaran yang mengintegrasikan berbagai kompetensi dari berbagai matapelajaran, terkecuali Pendidikan Agama dan Budi Pekerti, ke dalam berbagai tema dengan menggunakan empat pendekatan, yaitu intra- disipliner, inter-disipliner, multi-disipliner, dan trans-disipliner sehingga mampu memberikan makna yang utuh kepada peserta didik.(Prastowo, Studi, Guru, \& Ibtidaiyah, 2013)

Berdasarkan observasi yang dilakukan di kelas IV SDN 09 Surau Gadang Siteba Kota Padang terlihat bahwa dalam proses pembelajaran guru cendrung melakukan metode ceramah dan tanyajawab, sehingga proses pembelajaran kurang menyenangkan sehingga siswa mudah merasa bosan. Pada saat proses pembelajaran terlihat kurangnya keaktivan peserta didik terhadap pembelajaran Tematik Terpadu, akibatnya berdampak pada hasil belajar peserta didik yang masih banyak di bawah kriteria ketuntasan minimum (KKM) yaitu 75 .

Nilai rata-rata semester I pembelajaran Tematik Terpadu masih jauh dari kriteria ketuntasan minimal (KKM). Terdapat bahwa nilai
Tematik Terpadu siswa masih di bawah KKM yang ditetapkan guru yakni 75. Ini berarti ketuntasan hasil belajar siswa masih sangat rendah.

Berdasarkan latar belakang masalah penulis memutuskan untuk melakukan pengamatan, guna memperbaiki proses pembelajaran dan hasil belajar Tematik Terpadu siswa. Salah satu upaya yang dilakukan guru untuk mencapai aktivitas dan hasil belajar Tematik Terpadu siswa, yaitu dengan menggunakan model pembelajaran kooperatiftipe think pair share. Zulfah, (2017) menyatakan bahwa Think Pair Share merupakan suatu cara yang efektif untuk membuat variasi suasana pola diskusi kelas, dengan asumsi bahwa semua resitasi atau diskusi membutuhkan pengaturan untuk mengendalikan kelas secara keseluruhan.

Berdasarkan masalah tersebut maka penulisan melakukan pengamatan dengan judul "Model Pembelajaran Kooperatif Tipe Think Pair Share, Aktivitas dan Hasil Belajar Peserta Didik.

Menurut (Firman, 2018) Belajar adalah serangkaian kegiatan untuk memperoleh sesuatu perubahan tingkah laku sebagai hasil dari pengalaman individu dalam interaksi dengan lingkungannya, yang menyangkut kognitif, afektif, dan Psikomotor. Adapun Menurut Hamalik (2012), "Belajar merupakan suatu proses, suatu kegiatan, dan bukan suatu hasil atau tujuan. Belajar bukan hanya mengingat, akan tetapi lebih luas dari itu, yakni mengalami”"

Menurut (Novita, 2014) menyatakan Pembelajaran adalah usaha untuk mengubah struktur kognitif, afektif dan psikomotor siswa melalui penataan belajar. Dengan kata lain, pembelajaran adalah proses untuk membantu peserta didik agar dapat belajar dengan baik. Perhatian berperan penting dalam pembelajaran, karena pembelajaran tidak akan terjadi tanpa perhatian. Guru harus melibatkan siswa secara aktif dalam kegiatan pembelajaran untuk menarik 
perhatian siswa. Salah satu upaya untuk melibatkan siswa secara aktif dalam kegiatan pembelajaran dapat dilakukan dengan menerapkan model pembelajaran aktif. (Firman, 2018b)

Zulfah, (2017) menyatakan bahwa Think Pair Share merupakan suatu cara yang efektif untuk membuat variasi suasana pola diskusi kelas, dengan asumsi bahwa semua resitasi atau diskusi membutuhkan pengaturan untuk mengendalikan kelas secara keseluruhan. Think Pair Share memiliki makna sebagai berikut:

1) Thinking, siswa diberi kesempatan untuk memikirkan ide-ide mereka tentang pertanyaan atau wacana yang diberikan oleh guru.

2) Pairing, siswa menentukan dengan siapa mereka akan berpasangan dengan tujuan agar siswa dapat berdiskusi dan mendalami ide-ide yang telah ditemukan masing-masing siswa.

3) Sharing, setelah ditemukan kesepakatan ideide pada masing-masing kelompok, lalu pada tahap ini ide-ide tersebut dibagikan kepada kelompok lain melalui kegiatan diskusi dan Tanya jawab. Hal tersebut dimaksudkan agar dari berbagai ide-ide yang mereka temukan, dapat ditemukan satu struktur yang integrative dari pengetahuan yang telah dipelajari. (Zulfah, 2017)

Aktivitas belajar merupakan kegiatan belajar yang harus dilaksanakan dengan giat, rajin, selalu berusaha dengan sungguh-sungguh melibatkan fisik maupun mental secara optimal yang meliputi Visual activities, Oral activities, Listening activities, Writing activities, Drawing activities, Motor activities, Mental activities, Emosional activities supaya mendapat prestasi yang gemilang (Rintayati \& Putro, 2011)

\section{METODE}

Jenis penelitian yang penulis gunakan adalah penelitian eksperimen. Populasi merupakan keseluruhan dari objek penelitian. Populasi dalam penelitian ini adalah seluruh siswa kelas IV SDN 09 Surau Gadang Siteba Kota Padang berjumlah 47 orang. Penelitian ini menggunakan kedua kelas sampel yaitu kelas ekperimen dan kelas kontrol.

Jenis data yang digunakan dalam penelitian ini adalah data kuantitatif. Data kuantitatif dari penelitian ini adalah data yang diambil dari data hasil belajar siswa kelas IV SDN 09 Surau Gadang Siteba Kota Padang setelah melakukan eksperimen. Instrumen penelitian yang digunakan dalam penelitian ini adalah tes hasil belajar. Soal yang telah diuji cobakan untuk melakukan validitas tes, reliabilitas, tingkat kesukaran, dan daya pembeda

\section{HASIL DAN PEMBAHASAN}

Berdasarkan penelitian yang telah dilakukan pada kelas IV SDN 09 Surau Gadang Padang diperoleh data tentang hasil belajar siswa dari soal pilihan ganda. Jumlah siswa pada kelas eksperimen adalah 22 orang siswa, sedangkan jumlah siswa pada kelas kontrol adalah 20 orang siswa. Berdasarkan analisis data skor hasil belajar siswa pada kelas sampel diperoleh perhitungan rata-rata, simpang baku, dan varian kedua kelas sampel.

Tabel 1. Analisi data skor hasil belajar

\begin{tabular}{|l|l|l|l|l|l|l|}
\hline Kelas & N & $\begin{array}{l}\text { Nilai } \\
\text { Tertinggi }\end{array}$ & $\begin{array}{l}\text { Nilai } \\
\text { Terendah }\end{array}$ & $\bar{X}$ & $S^{2}$ & S \\
\hline Eksperimen & 22 & 95 & 65 & 80,23 & 43,9933 & 6,63 \\
\hline Kontrol & 20 & 85 & 60 & 76 & 38,4210 & 6,20 \\
\hline
\end{tabular}

Penelitian dimulai pada tanggal 03 Mei 2017 s/d 10 Mei 2017. Pelaksanaan penelitian pada kelas eksperimen dan kelas kontrol, yang bertindak sebagai guru adalah peneliti.

Uji normalitas bertujuan untuk mengetahui apakah data kedua kelas sampel terdistribusi normal atau tidak. Uji normalitas dilakukan dengan menggunakan rumus uji Lilifors yang dilakukan pada kedua kelas sampel. Dari uji 
2128 Pengaruh model pembelajaran kooperatif tipe TPS terhadap aktivitas dan hasil belajar peserta didikNuri Hayatul Jannah, Mudjiran

normalitas yang dilakukan, maka didapatkan harga $\mathrm{L} 0<$ Ltabel pada taraf nyata $\alpha=0,05$ seperti pada tabel berikut ini.

Tabel 2. Uji Normalitas

\begin{tabular}{|c|c|c|c|c|}
\hline Kelas & $N$ & $\mathrm{~L}_{\text {bitumg }}$ & $\mathrm{L}_{\text {tabel }}$ & Keterangan \\
\hline Eksperimen & 22 & 0,1484 & 0,1832 & Normal \\
\hline Kontrol & 20 & 0,1578 & 0,190 & Normal \\
\hline
\end{tabular}

Dari tabel diatas dapat dilihat bahwa harga Lhitung lebih kecil dari Ltabel sehingga dapat disimpulkan data kedua kelas sampel terdistribusi normal.

Uji homogenitas bertujuan untuk mengetahui apakah data hasil belajar kedua kelas memiliki varians yang homogen atau tidak.Dalam pengujian homogenitas digunakan uji $F$. Uji homogenitas dapat dilihat pada tabel berikut ini.

Tabel 3. Uji Homogenitas

\begin{tabular}{|c|c|c|c|c|c|}
\hline Kelas & $\mathrm{N}$ & " & $\mathrm{F}_{\text {litum }}$ & $\mathrm{F}_{\text {tbbel }}$ & Keterangan \\
\hline Elsspeiment & 22 & \multirow{2}{*}{0,05} & \multirow{2}{*}{1,15} & \multirow{2}{*}{2,18} & \multirow{2}{*}{ Hongongen } \\
\hline Koatiol & 20 & & & & \\
\hline
\end{tabular}

Berdasarkan tabel untuk Ftabel pada taraf nyata $\alpha=0,05$ dengan dk pembilang $=21^{`} \mathrm{dan} \mathrm{dk}$ penyebut $=19$ adalah 2,18. Berarti Fhitung $<$ Ftabeldimana $1,15<2,18$. Dengan demikian kedua kelas sampel memiliki varians yang homogen.

Setelah dilakukan uji normalitas dan uji homogenitas, dapat disimpulkan kedua kelas sampel berdistribusi normal dan memiliki varians yang homogen. jadi uji hipotesis yang digunakan adalah uji-t. Uji hipotesis dapat dilihat pada tabel berikut ini.

Tabel 4. Uji Hipotesis

\begin{tabular}{c|c|c|c|c|c|}
\hline Kelas & $\mathbf{N}$ & $\bar{X}$ & Dk & $\mathrm{T}_{\text {hitung }}$ & $\begin{array}{c}\text { Tabel taraf } \\
\text { nyata 0,05 }\end{array}$ \\
\hline Eksperimen & 22 & 80,22 & \multirow{2}{*}{40} & 2,19 & 2,02 \\
\hline Konttrol & 20 & 76 & & \\
\hline
\end{tabular}

Hasil uji hipotesis dengan menggunakan uji t yang dilakukan maka Diperoleh harga thitung dan ttabeldengan $\mathrm{dk}=\mathrm{n} 1+\mathrm{n} 2-2=22+20-2=$ 40yang terletak pada tabel diantara ttabel 40 dan 60 pada taraf nyata $\alpha=0,05$ dengan t0,975 diperoleh ttabel 2,02 maka thitung $=2,19$ dan ttabel $=2,02$. Hal ini berarti thitung $>$ ttabel, dimana 2,19>2,02 dengan demikian H1 diterima yaitu Terdapat perbedaan antara hasil belajar Matematika siswa yang menggunakan model Think Pair Share dengan hasil belajar Matematika siswa yang menggunakan pembelajaran konvensional di kelasIV SDN 09 Surau Gadang Padang.

Berdasarkan sampel ditemukan bahwa kedua kelas sampel data terdistribusi normal dan homogen. Kondisi ini memberikan peluang pengujian hipotesis menggunakan uji t. Uji t yang dilakukan, diperoleh t-hitung 2,19 sedangkan ttabel 2,016. Berdasarkan derajat $t$ dengan derajat bebas 40 adalah 2,016 maka dapat dilihat bahwa penggunaan model Think Pair Share dalam pembelajaran Matematika memberikan pengaruh yang berarti terhadap hasil belajar siswa kelas IV SDN 09 Surau Gadang Padang. Perbedaan hasil belajar antara kelas eksperimen dan kelas kontrol disebabkan karena kedua kelas sampel diberikan perlakuan pembelajaran yang berbeda. Hal ini menunjukkan dengan model Think Pair Share pada kelas eksperimen diperoleh hasil belajar yang lebih baik dari pada penggunaan pembelajaran konvensional pada kelas kontrol.

\section{SIMPULAN}

Berdasarkan hasil penelitian yang telah dilakukan maka dapat disimpulkan yaitu hasil belajar Matematika siswa kelas IV SDN 09 Surau Gadang Padang yang menggunakan model Think Pair Share lebih baik dari hasil belajar Matematika siswa yang menggunakan pembelajaran konvensional yanf dapat dilihat dari hasil uji hipotesis dengan menggunakan uji $t$ yang dilakukan maka dan diperoleh harga thitung dan ttabel dengan $\mathrm{dk}=\mathrm{n} 1+\mathrm{n} 2-2=22+20-2=40$ yang 
2129 Pengaruh model pembelajaran kooperatif tipe TPS terhadap aktivitas dan hasil belajar peserta didikNuri Hayatul Jannah, Mudjiran

terletak pada tabel diantara ttabel 40 dan 60 pada taraf nyata $\alpha=0,05$ dengan t0,975 diperoleh ttabel 2,016 maka thitung $=2,19$ dan ttabel $=2,02$. Hal ini berarti thitung>ttabel, dimana 2,19>2,02 dengan demikian $\mathrm{H} 1$ diterima.

Karena pembelajaran dengan menggunakan model Think Pair Share siswa dapat bekerja sama dan saling menghargai sesama anggota kelompoknya sertasiswa akan lebih semangat mengikuti pelajran karena ada kegiatan permainan dan turnamen dalam model ini. Sehingga hasil belajar pada kelas eksperimen lebih baik daripada hasil belajar pada kelas kontrol, hal ini terlihat dari nilai rata-rata pada kelas eksperimen lebih tinggi dari nilai rata-rata kelas kontrol.

\section{DAFTAR PUSTAKA}

Firman. (2018a). Efektivitas Layanan Penguasaan Konten Menggunakan Model Pembelajaran Kooperatif Tipe Think Pair Share Untuk Meningkatkan Keterampilan Bertanya Siswa Dalam Belajar, (November), 1. Https://Doi.Org/DOI: 10.24036/00370

Firman, Lubis Dan. (2018b). Pengaruh Model Role Playing Terhadap Sikap Empati Dan Hasil Belajar IPA Pada Pembelajaran Tematik Terpadu Siswa Kelas V Sdn 20 Kurao Pagang Kota Padang Oleh, (January).

Lubis, A. (2012). The Effect Of Phase Noise, 1(1), 27-32. Https://Doi.Org/SO0223999(06)00261-3 [Pii]

Novita, R. (2014). Efektivitas Model Pembelajaran Kooperatif Tipe Think Pair Share (TPS) Pada Materi Trigonometri Di Kelas XI IA1 SMA Negeri 8 Banda Aceh. Visipena, 5(1), 128135. Retrieved From Http://Visipena.Stkipgetsempena.Ac.Id/Hom e/Article/View/77/78

Prastowo, A., Studi, P., Guru, P., \&Ibtidaiyah, M. (2013). Female Directors And Earnings Quality._Ebscohost, 1-13.

Rintayati, P., \&Putro, S. P. (2011). Meningkatkan Aktivitas Belajar ( Active Learning ) Siswa Berkarakter Cerdas Dengan Pendekatan Sains Teknologi (Stm)Oleh: Peduk Rintayati Dan Sulistya Partomo Putro Prodi PGSD
FKIP Universitas Sebelas Maret Surakarta.

Zulfah. (2017). Pengaruh Penerapan Model Pembelajaran Kooperatif Tipe Think Pair Share Dengan Pendekatan Heuristik. Journal Cendekia: Jurnal Pendidikan Matematika, 1(2), 1-12.

Hamalik, Oemar. 2012. Proses Belajar Mengajar. Jakarta: Bumi Aksara. 